centrum lakóövezetébe sorolja, esetleg alvótelepülésnek nevezi. Pedig az itt élö emberek messze nem csak aludni járnak haza. Számukra elengedhetetlenül fontos az otthon végzett mezőgazdasági munka. Egy mindezt figyelembe vevö, sokkal kevésbé ,várospárti" megközelítésben pedig ezek a falvak - az akár 80\%-os ingázási arány ellenére is - lakó- és munkahely egy ségének tekinthetók. Meggyőződésem, hogy nem csupán terminológiai kérdésról van szó. Az a - könyvben is felvetett - tény húzódik meg mögötte, hogy bár ez a lakosság egyszerre éli a városi munkás és a falusi gazda életét, az utóbbiról a társadalom alig vesz tudomást. Ennek negatív hatásait részletesen elemzi a szerzô. Közülük emelhetók ki az alábbiak:

- Az ingázó férfiak magukra is a város szabályrendszerét tekintették érvényesnek. A falu parancsai közt felnóve s továbbra is ebben a környezetben megmaradva azonban sokuk, ,sem öntudatos munkás, sem magabíró paraszt nem lehetett", s a kudarc alkoholizmushoz vezetett.

- Féló, hogy a ma pályát választó nemzedék nem vállalja a társadalmi peremhelyzetet. Gazdálkodásuk kiesése pedig nemcsak a falu létét fenyegeti, hanem a várost is megfosztja a megtermelt javaktól.

- Ha a zöldségellátás a jövóben is a kistermelőkre hárul, és a zöldség ára a termelésre vállalkozók számának csökkenésével egyenes arányban nö, akkor - a szerzö gondolatait folytatva - egyre sürgetóbb lesz az a kérdés is, hogy mire fogja költeni a pénzét az emeletes házzal, autóval rendelkezó gazda, ha továbbra sem lesz mód a mezógazdasági tókeakkumulációra.

Ez a kérdésfelvetés azzal a közgazdasági szemlélettel vihetö tovább, miszerint a lakosság önkéntes, vállalkozásokba való pénzbefektetése révén elósegíthetó volna a termelés kiszélesítése, a hiány mérséklése, s ezáltal az indokolatlan jövedelem-differenciák megszüntetése is. Mindezek pedig igen fontos szerepet játszhatnak a hasonló adottságú falvak fennmaradásában. A gazdaság alacsony színvonalához, az ellátóképesség hiányosságaihoz ugyanis nemegyszer még az is hozzájárul, hogy a közösség sem jelent kelló megtartóerót. ÓRSZIGETHY Erzsébet feltárja a helyi társadalmi szervezet megfeleló intézményesültségének, az érdekképviseletnek a hiányát, pontos magyarázatot ad a falusiak ,felháboritó közömbösségére". E súlyos gondok bemutatása mellett képet kaphatunk a házassági, lakodalmi szokásokról, a falusiak életének számos részletérôl. A leírásokat szemléletessé, olvasmányossá teszik a személyes vallomások, párbeszédek, annak ellenére, hogy ezek időnként ismétlésekhez vezetnek s megtörik a könyv logikai menetét. Könnyen megbocsájtható azonban, hogy az asszonykórus tagjainak színes elbeszélései néha magukkal sodorták a szerzőt is. Láthatóan közel került hozzájuk, ismeri, érti óket. Nem az ó érdekeik ellen, hanem a falu érdekében fogalmazta meg, akár összegzésnek is tekinthetô állítását: ,Nem vitatom a kórus népdaltudását és éneklótehetségét, az asszonyok színpadra és dologra valóságát még kevésbé. De azt már természetellenesnek, az. állam és állampolgára között mindig is meglévô társadalmi szerzödés megcsúfolásának érzen, hogy egy olyan falu, amely a nemzetgazdaság számára nélkülözhetetlen produktumok sorát képes létrehozni, a nagyvilág előtt csak és kizárólag dalkultúrájával szerepel. Nem termelési kultúrájával, az élete rendjét szervezó munkája eredményeivel".

\title{
A BALATON ÉS AZ IDEGENFORGALOM (GERTIG BÉLA ÉS LEHMANN ANTAL SZERK.)
}

\author{
(JPTE Tanárképzö Kar, Pécs, 1985. 232 p.)
}

A Janus Pannonius Tudományegyetem Földrajz Tanszékének oktatói az clmúlt években állami megbízásból ,,A természeti környe- zet és a társadalmi-gazdasági szerkezet, valamint ezck földrajzi kapcsolatrendszere a Balaton térségében" címú témában véguztek kutatásokat. 
A kötet 6 tanulmánya e munka eredményeit teszi közzé.

Kutatásunk célja az volt, hogy a Balaton térségéröl - pontosabban a Minisztertanács 1013/1979. (VI.20.) sz. határozatában és az ezt módosító 4/1983. (III.3.) ẼVM. sz. hatårozatban fölsorolt településekrỏl - átfogó földrajzi szemléletú területjellemzést készítsenek, megkülönböztetett figyelmet szentelve az idegenforgalomnak mint fö funkciónak. Ez a törekvés azért is üdvözlendő, mert a földrajztudomány az utóbbi évtizedekben egyre inkább háttérbe szorult a legnagyobb tavunk körül jelentkező problémák föltárásában, megoldásában.

A kutatásokat alapvetően két fő csoportra összpontositották: mikortól és hogyan hasznosította az ember a természeti és társadalmi-gazdasági adottságokat az idegenforgalom érdekében. illetve mikẻppen hatott vissza az idegenforgalom a társadalomra és földrajzi környezetére.

Az első tanulmányban Lehmann Antal a Balaton üdülökörzet természeti környezeti adottságait vette számba. A körzet idegenforgaimi vonzercjének megórzése érdekében a természetés a környezetvédelem szempontjait elótérbe helyezve elemzi a terület geológiai fölépitését, domborzatát, talajait, éghajlatát, vízrajzát, természetes növény - és âllatvilágát. Több esetben rámutat a már bekövetkezett környezetkárosítások kiküszöbölési módjaira.

A második tanulmány szerzője, Gertig Béla, a térség idegenforgalmát jellemzi. Érdekes gondolatokat vet föl a különbözö szálláshelyek telephelyválasztására ható természe ti és társadalmi-gazdasági tényezók vizsgálata során (pl. a kòzlekedési helyzet szerepe, a mind sưrübb beépítés köve tkezményei stb.). Külön fejezetrészt szentel az üdülökörzet vendégforgalma legnehezebben számitható eleme - a hétvégi forgalom - alakulásának. Saját kutatási eredményeire alapozott fejlesztési javaslataival csak részben értek cgyet. Véleményem szerint nem a féröhelykapacitás gyors bỏvítésével - Fonyódon, Balatongyörökön és Révfülöpön - szolgáljuk leghatékonyabban az idegenforgalom, illetve a Balaton ügyét. hanem a már meglevő szálláshelyck minőségét, választékát kèllene javítani.

Sikó Ägnes az üdủlökörzet népesség-és településföldrajzi jellcuroóit tckinti át 1870-tốl napjainkig. A népessíg fẹjlődését vizsgálva rámutat. hogy 1970 után többnyire azokra a településekbe folytatódott a bevándorlás, amelyck funkciója szélcsebb körü, mint a szczonális üdültc- tés. Településföldrajzi vizsgálata a településhálózat alakulására, az urbanizációs folyamat helyzetére, a funkcionális változásokra és a településképet meghatározó üdülö- és lakásállomány viszonyåra terjedt ki.

Vuics Tibor a térség élelmiszergazdaságát tanulmányozva mutatja be a mezógazdaság termelési szerkezetét, színvonalát, munkaerögondjait. Elemzi a kereskedelem szerepét a megnövekedett idegenforgalomból fakadó igények kielégítésében, és rámutat a tároló- és hủtókapacitás hiånyosságaira. $\mathrm{Az}$ állattenyésztés helyzetének ismertetése utån azt javasolja, hogy a húsellátás javitása érdekében a feldolgozó tevékenység részleges vagy teljes vertikumát alakítsák ki pl. az egyes, ,háttértelepü lések ben". A mezôgazdaság környezetkímélö fejlesztési alternatíváit is ismerteti a tanulmány.

Aubert Antal az üdülókörzet iparáról ad történeti áttekintést. Kijelenti, hogy a Balaton egyre nagyobb idegenforgalma mindinkább olyan iparszerkezetet kiván meg, amely ezt a tevékenységi kört szolgålja. Igy Somugy megyében kedvezőnek itéli az élelmiszeripar magas arányát. Közvetlen környezetátalakító hatása miatt kiemeli a bányászatot, kảros következményeit konkrét példákkal illusztrálja. Végül ipari vonzáskörzeteket határol el az üdülökörzet területén.

Mohos Måria az infrastruktúra jellemző vonásait tárta föl az údülókörzetben. Rámutat, hogy az infrastruktúrával szembeni igény szezonálisan jelentkezik, s ez nehezíti az infrastruktúra elemeinek tervezését, müködtetését. Rávilágít arra a sajnálatos tényre, hogy a közüzemi csatornahálózatba bekapcsolt lakások aránya még mindig csak az országos átlag egyharmadát ćri el, nem kevéssé veszćlyeztetve ezzel a Balaton vízminőségét. A közlekedés helyzetét elemezve hátrányosnak tartja. a fổ közlekedési útvonalak keskeny parti sávban való elhelyezkedését, továbbá a háttértelepüléseket a fôvonalla! összekötő utak alacsony számát. Megállapítja, hogy az üdülési szezonban továbbra is komoly feladatot jelent a kiskereskedelem. a vendéglátás és az egészségügyi ellátás minden igényt kiclégítỏ megszervezése.

A tanulmányokat értékes információkat tartalmazó térképek, diagranok, táblázatok teszik teljescbbé. Egy apró formai hiányosság: Sikó Ágnes munkájában a 34. ábrasorról lemaradt az „a, b, c” jelzés, de jelentéstartalmuk kikövetkeztethetô. A kötet részletes bibliográfiåval zárul.

Kraftné Somogyi Gabriella 